\title{
The medical life of Henry Norman Bethune
}

\author{
Jean Deslauriers MD FRCSC ${ }^{1}$, Denis Goulet $\mathrm{PhD}^{2,3}$
}

\author{
J Deslauriers, D Goulet. The medical life of Henry Norman Bethune. \\ Can Respir J 2015;22(6):e32-e42.
}

BACKGROUND: Henry Norman Bethune is one of the most exciting and incredible surgeons that Canada has ever produced. Indeed, he is often characterized as one of the world's best-known surgeons. He was an innovator and his scientific contributions have stood the test of time. In Canada, he will forever be remembered as a social activist committed to the welfare of the poor and to the reform of the health care system. In the People's Republic of China, he is idolized and remains the only foreigner to ever become a national hero.

OBJECTIVE: To detail the numerous and significant achievements of Henry Norman Bethune in the field of thoracic surgery and as a social activist and describe his heroic war-time actions on the battlefields of both Spain and China.

METHOD: Information was gathered through the reading of the numerous publications written about the life and work of Bethune, interviews with knowledgeable people from Canadian and Chinese universities, analysis of Bethune's own publications, and extensive experience of one of the authors in China.

RESULTS: In the social sense, Henry Norman Bethune had a difficult personality, but he was deeply caring about the plight of his patients, especially the poor. As a thoracic surgeon, he could be ingenious, thoughtful and effective but he could also be abrasive, restless and temperamental. His scientific contributions were sound and, at the time, gained worldwide attention. As an activist, he led a crusade to reform the Canadian health care system, demanding free health care for all. His outstanding work during the Spanish Civil War, where he organized the first ever mobile blood transfusion unit, and during the Sino-Japanese war, where he was totally committed to the welfare of both soldiers and civilian population, were deliberate acts of resistance against Fascist onslaught and enthusiasm for the Communist cause. CONCLUSIONS: Henry Norman Bethune was unconventional and a revolutionary, but he was brilliant. He will forever be remembered as an innovative thoracic surgeon and outstanding humanitarian.

\section{La Vie Médicale de Henry Norman Bethune}

HISTORIQUE : Henry Norman Bethune a été l'un des chirurgiens les plus excitants et incroyables qui n'ait jamais vu le jour au Canada. Il est d'ailleurs souvent considéré comme l'un des chirurgiens les mieux connus sur la planète. Il était un innovateur et ses contributions scientifiques ont marqué son époque. Au Canada, il a laissé l'image d'un activiste dédié à la cause des pauvres et à la réforme du système de santé. En République Populaire de Chine, il demeure à ce jour le seul étranger à n'avoir jamais obtenu le titre de Héros National.

OBJECTIF : Détailler les nombreuses et importantes réalisations de Bethune dans le domaine de la chirurgie thoracique, présenter ses engagements sociaux et décrire ses actions héroïques sur les champs de bataille d'Espagne et de Chine.

MÉTHODES : Lecture des nombreuses publications sur la vie et le travail de Bethune, entrevues avec personnes bien informées dans plusieurs universités Chinoises et Canadiennes, analyse des publications de Bethune lui-même et expérience extensive d'un des auteurs en Chine.

RÉSULTATS : Sur le plan social, Bethune avait une personnalité difficile mais il a cependant toujours été très préoccupé par le bien-être de ses malades, particulièrement celui des pauvres. Comme chirurgien thoracique, il était ingénieux, réfléchi et audacieux mais il pouvait aussi se montrer irascible et impétueux. Ses contributions scientifiques lui ont permis d'atteindre une certaine notoriété. En tant qu'activiste social militant, il a mené une croisade pour réformer le système de santé Canadien dans le but d'obtenir la gratuité des soins pour tous. Ses activités durant la guerre civile en Espagne, où il a mis sur pied le premier service mobile de transfusion sanguine et plus tard durant la guerre Sino-Japonaise ou il a été reconnu pour son dévouement autant sur le champ de bataille qu'envers la population civile ont été des actes délibérés de résistance à la montée du fascisme et de soutien envers le système communiste.

CONCLUSION : Peu conventionnel, Bethune était un homme brillant, un chirurgien thoracique innovateur et un grand humaniste.

Key Words: Canadian health care system; Mobile transfusion unit; Norman Bethune; Sino-Japanese war; Spanish Civil War; Thoracic surgery

I $\mathrm{t}$ is an enormously difficult task to write about the medical life of Henry Norman Bethune (Figure 1), who was one of the most exciting and incredible surgeons that Canada has ever produced. Indeed, the late Alexander Walt once categorized him as the world's best-known surgeon (1). He was unconventional but brilliant (2). In the social sense, he had a difficult personality but he was deeply caring about the plight of his patients, especially the poor. Professionally, he could be ingenious and thoughtful but, at the same time, could also be abrasive and temperamental. He performed surgery with great speed and a certain calculated flamboyance. He was an innovative surgeon whose research work was productive and, at the time, gained worldwide attention.

In his early years, he faced more challenges than most surgeons are ever called to endure including wartime experiences during World War 1 , and a serious attack of tuberculosis requiring pneumothorax treatment.

In 1935, while working in Montreal, he joined the Communist party and began a crusade to reform the Canadian health care system which he thought was "incredibly backward". He decried the fact that

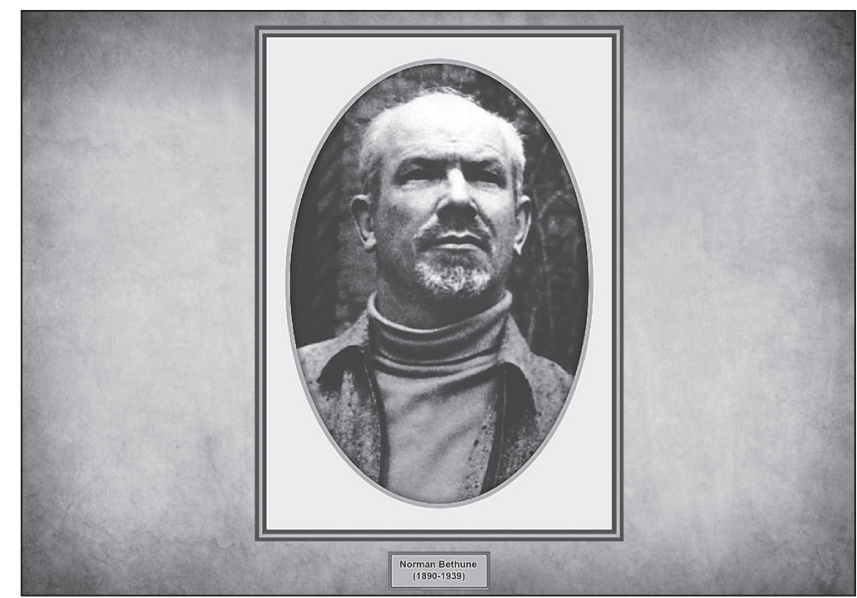

Figure 1) Henry Norman Bethune

${ }^{1}$ Institut Universitaire de Cardiologie et de Pneumologie de Québec; ${ }^{2}$ Faculté de Médecine de l'Université de Montréal, Montreal; ${ }^{3}$ Faculté de

Médecine et des Sciences de la Santé, Université de Sherbrooke et Département d'Histoire, UQUAM, Quebec

Correspondence: Dr Jean Deslauriers, 652 Chemin Royal, Saint-Laurent, Ile d'Orléans, Quebec G0A-3Z0.

Telephone 418-829-3043, fax 418-656-4762, e-mail jean.deslauriers@chg.ulaval.ca 


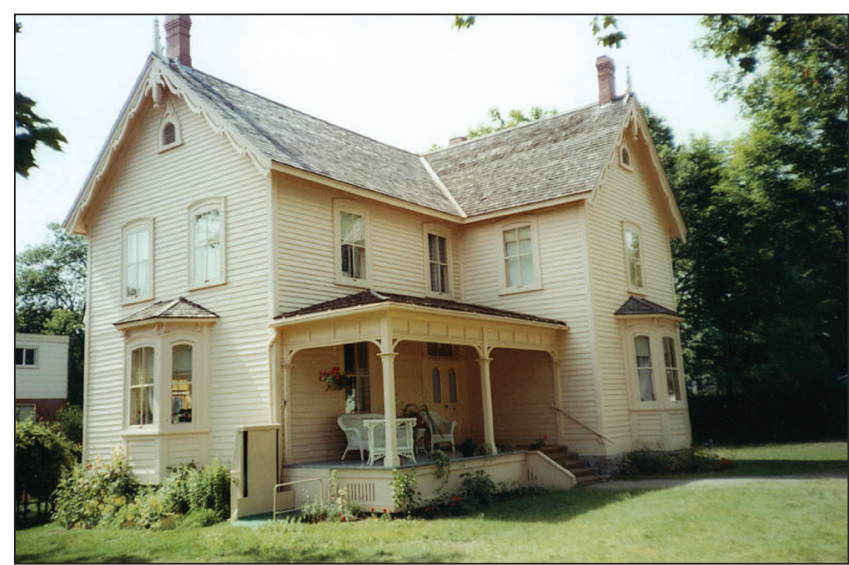

Figure 2) Photograph of the Bethune Memorial House in Gravenhurst, Ontario. The house was built in 1880 to serve as the Manse of the Knox Presbyterian Church. Reverend Malcolm N Bethune, Norman's father, and his family moved into it in 1889. In 1973, it was acquired by the Canadian government and was officially opened as a Canadian Memorial in 1976

doctors should benefit from a person's illness and demanded free health care for all and salary for doctors.

In 1936, he believed that the time to fight fascism had come and the outbreak of the Spanish Civil War provided him the opportunity. He went to Madrid where he organized the first ever mobile transfusion unit. The paramedics, created during World War II, became an extension of his ideas.

In 1937, he recognized that the Sino-Japanese conflict in the most populous country of the world was to be a momentous event and he volunteered to go to China and organize medical services for the Mao Tse-Tung Eight Route Army. In that country, his achievements were numerous and he showed the value of prompt medical assistance to wounded soldiers by bringing the surgeon to the wounded on the battlefield. He reorganized what was then primitive medicine, trained doctors (Barefoot Doctors) and nurses, and established what his Chinese colleagues called "Model Hospitals". He won the admiration of the Chinese people by accepting their customs, sleeping in their homes and donating his own blood without hesitation.

\section{THE BEGINNING (1890-1926)}

Henry Norman Bethune was born March 3, 1890 in Gravenhurst, Ontario (Figure 2), a small lumbering town, $160 \mathrm{~km}$ north of Toronto. Both of his parents, Malcolm Nicholson Bethune and Elizabeth Ann Goodwin, were Presbyterian ministers highly influenced by the Evangelical movement of Moody and Sankey (3).

Bethune's grandfather, Norman (1822-1892) had been a military surgeon during the Crimean war alongside Henri Dunant, founder of the Red Cross and also a military surgeon. Bethune's grandfather was also well known in Canada because he had been involved in establishing Toronto's third medical school, the Upper Canada School of Medicine. One of three children, Bethune venerated his grandfather and, from his early years, everybody knew that he also wanted to become a great surgeon. His parents even claim that, when he was eight years old, he hung the nameplate of his surgeon grandfather in his bedroom and insisted that he be called Norman rather than Henry (4).

In an interesting publication on the Bethune genealogy before their emigrating from Scotland to North America in 1773, Munro and Macintyre showed that the family descended directly from the Bethune or Beaton medical dynasty who, for generations, had served as physicians to kings of Scotland and some of the largest Scottish clans (3). According to experts, many of his ancestor's characteristics are clearly discernable in Bethune's complex character: disdain for authority, intolerance of systems, impatience, depth of conviction, abrasiveness and independence $(1,5)$.

When he was young, Bethune had to move frequently because of his father's commitment to an itinerant ministry of the poor but,

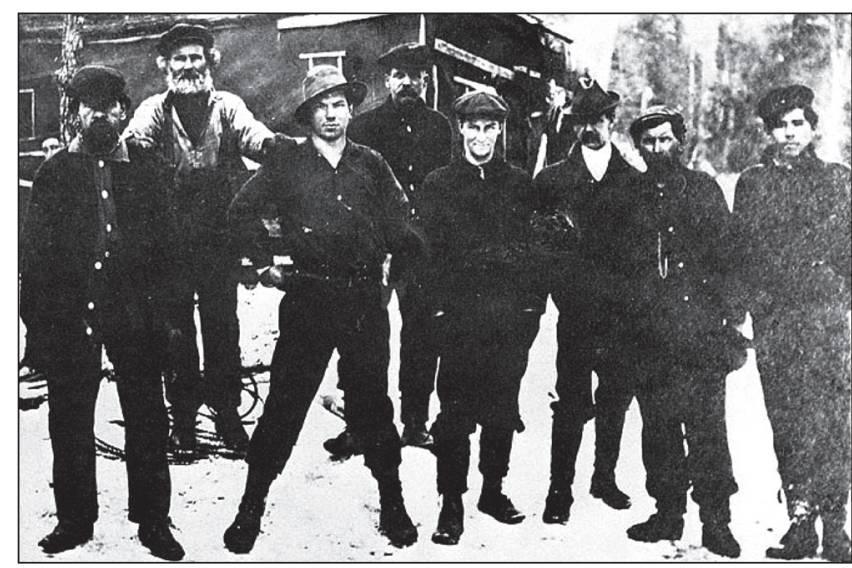

Figure 3) In 1911, Norman Bethune (third from left) interrupted his studies in physiology and biochemistry at the University of Toronto to work as a bush lumberjack in northern Ontario. During the day, he would work as a lumber jack, and at night, he would teach English to newly arrived Canadian immigrants. This is where he developed a sympathy for the poorly educated and an understanding of foreigners

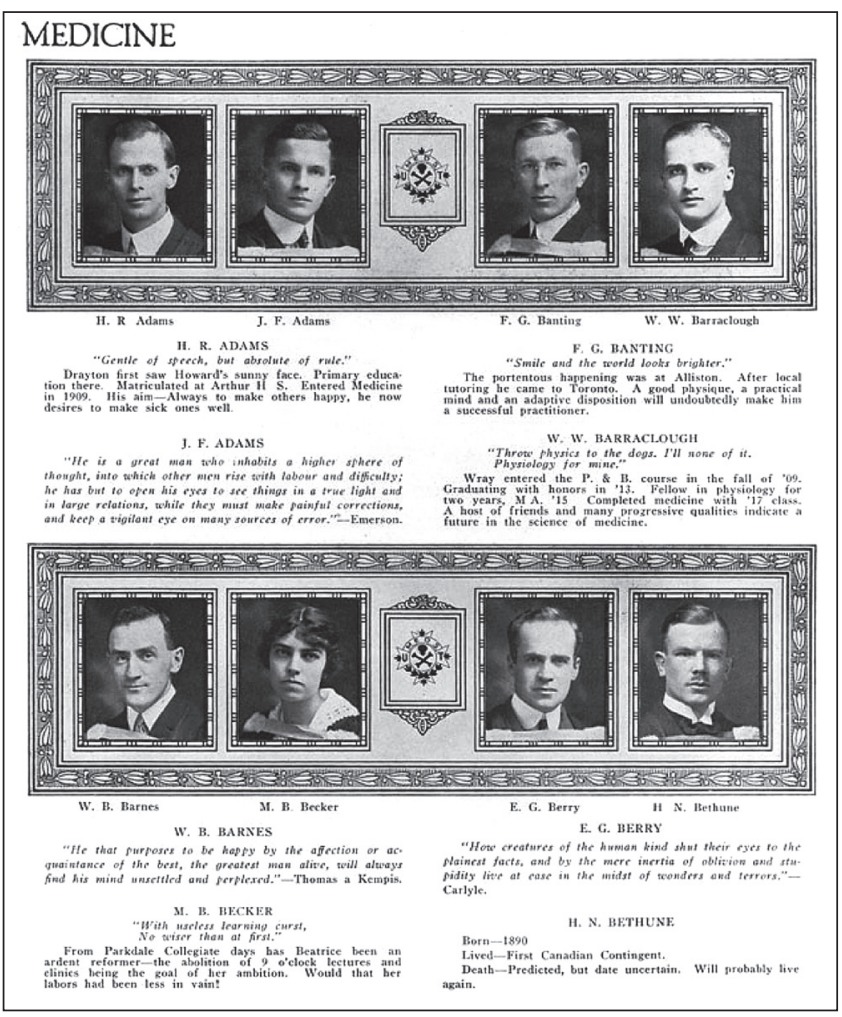

Figure 4) University of Toronto Medical School Graduation Class of 1916. Frederick Banting is in the top row, second from the right, and Norman Bethune is in the bottom row, first from the right.

despite such relocations, he graduated from Owen Sound Collegiate high school with a good academic record.

Eventually, the Bethune family settled in Toronto so that Norman could have a better education and, in 1909, he entered the University of Toronto to study physiology and biochemistry (6).

To help cover the costs of his education, he sometimes had to interrupt his studies and do a variety of jobs, including those of lumberjack, English teacher for Canadian immigrants (Frontier College) (Figure 3), and reporter for the Winnipeg Telegram. According to Alexander Walt, these early experiences sharpened Bethune's self-reliance, physical toughness and teaching skills (1). 


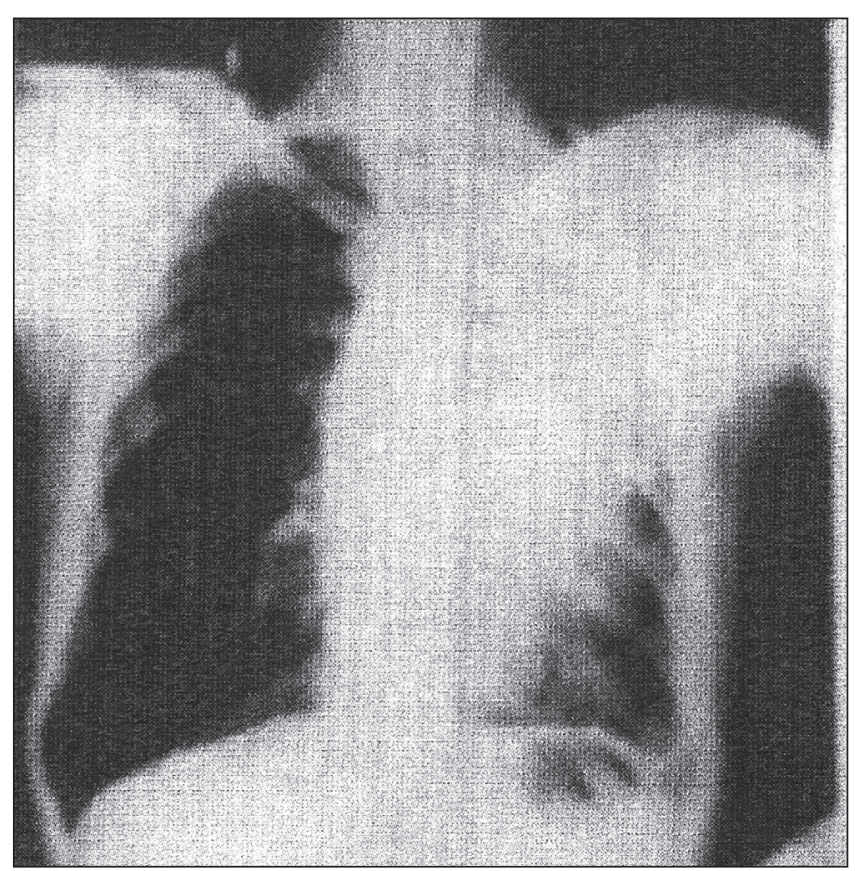

Figure 5) Posteroanterior chest radiograph of Norman Bethune on arrival at the Trudeau Sanatorium in December 1926. The $x$-ray shows severe tuberculous pneumonia of the left upper lobe
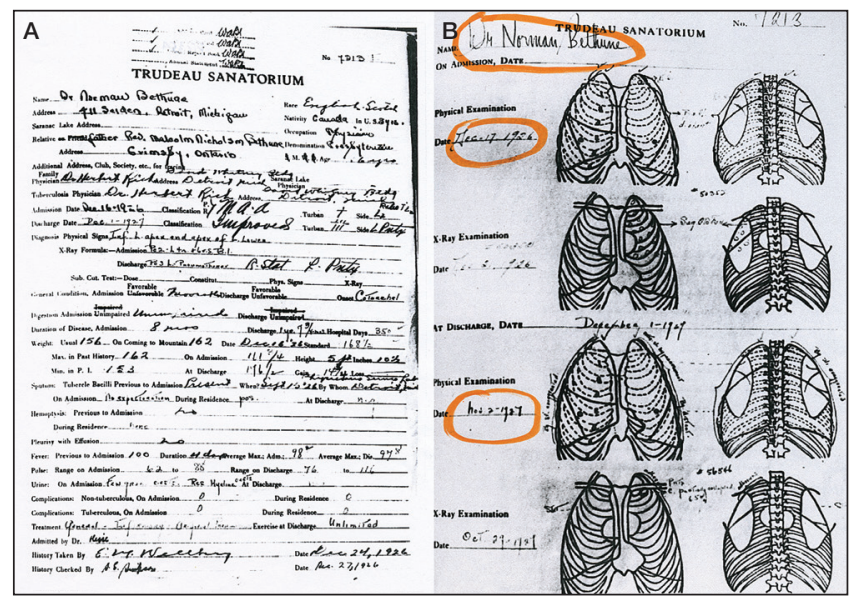

Figure 6) Bethune's medical chart at the Trudeau Sanatorium. A Discharge summary; B Diagram of Bethune's x-rays showing left upper lobe tuberculous pneumonia upon arrival (second line) and clearing of the lesions after his therapeutic pneumothorax (bottom line)

In 1912, he entered medical school at the University of Toronto, but elected to enlist in the Royal Canadian Army Medical Corps at the outbreak of World War I in September 1914. At the age of 24, he saw combat in France as a stretcher bearer and six months later, sustained a severe shrapnel leg injury during the battle of Ypres (Belgium), a battle that became famous because chemical weapons (chlorine) were used by the Germans. His experiences as a stretcher bearer probably taught him the importance of immediate medical assistance to the wounded on the battlefield, a feature which later became his modus operandi in Spain and China.

After his convalescence, he completed a crash course in medicine and graduated in 1916. Interestingly, one of his classmates was Frederick Banting (Figure 4), who was to receive the 1923 Nobel Prize in Medicine for his discovery of insulin $(7,8)$.

In 1917, Bethune volunteered again for military duties and was commissioned overseas as a lieutenant-surgeon in the Royal Navy. He

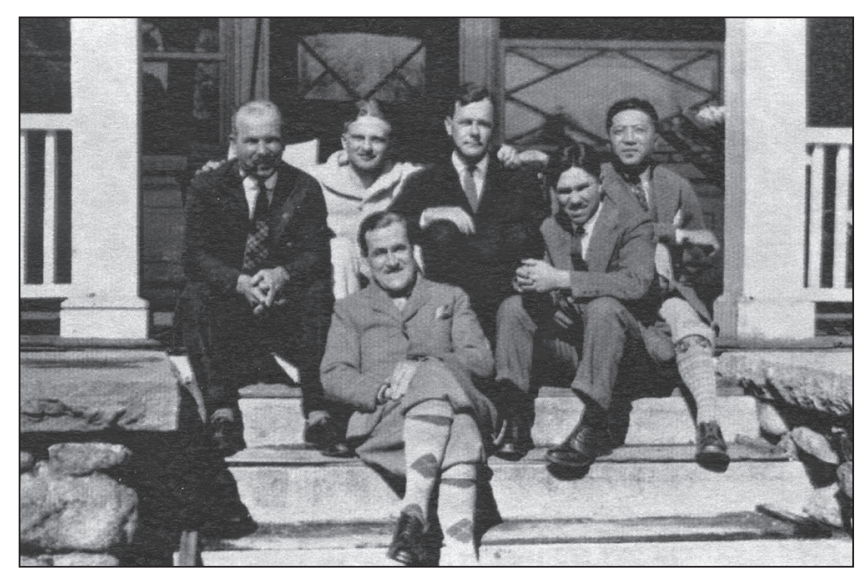

Figure 7) Photograph of the patients who were housed in the Lea Cabin at the Trudeau Sanatorium in 1927. They included Norman Bethune (smoking the pipe), Alfred Blalock, who became world famous for his work on congenital heart disease (second from right), and John Barnwell, who became the Head of the Tuberculous Unit at Ann Arbor (sitting on the lower stair).

was subsequently transferred to the Canadian Flying Corps, where he served as a medical officer until the end of the war. After the war, Bethune spent three years as a surgical house officer in both London and Edinburgh and, in 1922, gained the status of Fellow of the Royal College of Edinburgh.

He then settled in Detroit, Michigan (USA) at a time when the city was expanding and opportunities for well-trained surgeons abounded (1). After a slow start, his surgical practice grew rapidly and, at 34 years of age, he became well known not only for being a competent thoracic surgeon but also for being a social activist and an outstanding teacher at Wayne State University.

\section{PERSONAL FIGHT AGAINST TUBERCULOSIS. CURE AT THE SANATORIUM (1926-1927)}

Toward the end of 1926, Bethune began experiencing fatigue, weight loss and hemoptysis, and tuberculosis was diagnosed. When he entered the Trudeau Sanatorium at Saranac Lake, New York (USA), in December 1926, he was severely ill with left upper lobe tuberculous pneumonia (Figure 5).

While researching tuberculosis and its treatment, he came across the writings of the famous American thoracic surgeon, John Alexander from Ann Arbor, Michigan, and instantly put his hopes for cure on a form of collapse therapy called 'artificially induced pneumothorax', a technique that had first been described at the end of the 19th century by an Italian physician, Carlo Forlanini (9).

Initially, the physicians at the sanatorium were reluctant to perform a procedure that they considered to be risky and advocated bed rest (the preferred therapy). After much discussion, however, one of the physicians, Dr Earle Warren, agreed to induce a therapeutic pneumothorax on Bethune's left lung. Unfortunately, Dr Warren accidentally punctured the lung, creating a tension pneumothorax, which had to be drained on an urgent basis. Despite this complication, Bethune made a complete recovery and, within two months, his sputum had turned negative and he was discharged from the sanatorium in December 1927 (Figure 6). For several years thereafter, Bethune continued to have 'pneumothorax refills' and even had a left phrenicectomy performed by John Alexander himself. His tuberculosis apparently never recurred despite the extreme conditions of deprivation of food and rest on the battlefields of China.

At the time, the Trudeau Sanatorium was restricted to patients with 'expected to recover' disease who underwent six months of therapy at a cost of $\$ 15.00$ per week including room, board and medical services. They were lodged in cabins, and Bethune's companions in the Lea Cabin included Alfred Blalock and John Barnwell, who pur- 

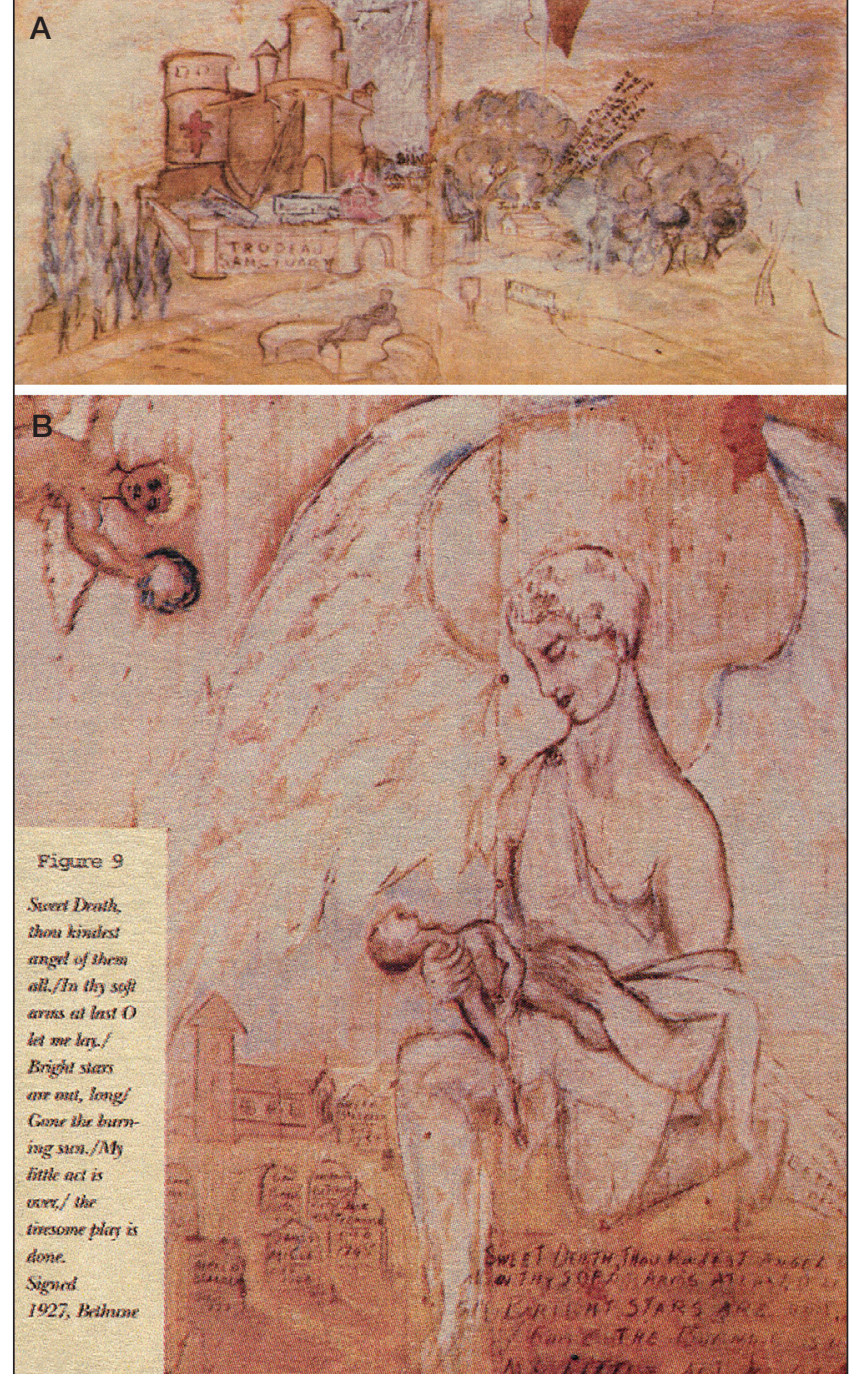

Figure 8) Murals painted by Bethune on the inner walls of Lea Cabin at the Trudeau Sanatorium. A Scene no 6 showing Bethune arriving at the sanatorium; B Scene no 9 showing the angel of death holding Bethune in his arms

sued distinguished careers in cardiac surgery and pulmonary medicine, respectively (Figure 7).

Initially on bed rest, Bethune was eventually allowed to be ambulatory. In obvious denial of his condition, he quickly became the life of the party, defying all rules and regulations, especially that of bed rest. He organized parties for patients and nurses, for which he supplied wine smuggled in from the neighboring province of Quebec. According to legend (source unknown), Alfred Blalock said the following about his life at the sanatorium:

I cured from tuberculosis (laid in bed, resting to recover) five days a week and sneaked into the village Saturday night to forget the cure; and cured Sunday to recover from Saturday night.

Often pessimistic with having to remain in bed, Bethune had ample opportunities for contemplation and introspection. His artistic sensibilities were sharpened and he initiated what eventually turned out to be a significant volume of artwork. His most important production was a multipanel mural entitled "Tuberculosis in Progress, a Drama in one Act and nine Painful Scenes" (Figures 8A and 8B). Drawn in colour on paper used to wrap laundry packages, the continuous panel covered the entire inner walls of the cabin and below each drawing was a poem describing the scene. The ninth drawing (Figure $8 \mathrm{~B}$ ) reflects Bethune's

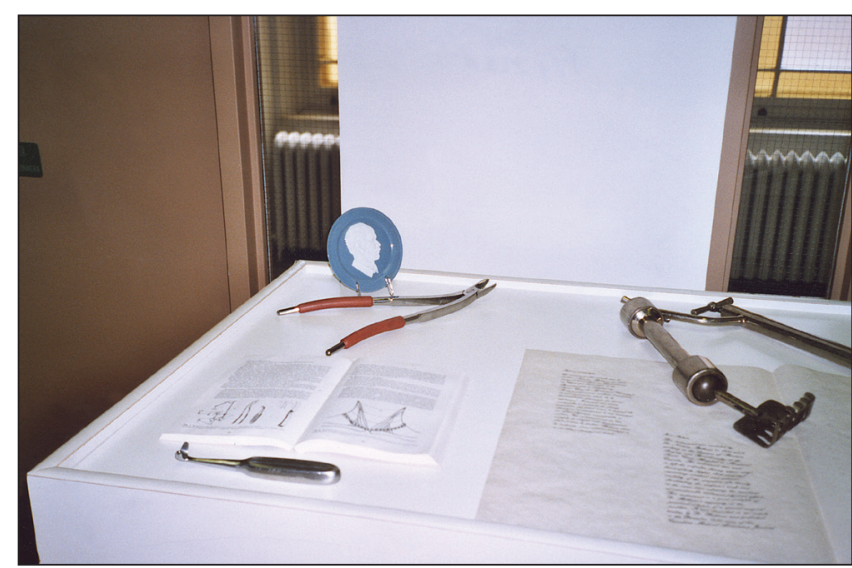

Figure 9) Original thoracic surgery instruments designed by Bethune and kept in a museum at l'Hôpital du Sacré-Coeur in Montreal. They include the rib shears (top left), the periosteum scraper (bottom left) and the tablemounted scapula retractor (right)

fear of impending doom and depicts the angel of death holding him in his arms. The poem reads as follows:

Sweet Death, thou kindest Angel of them all,

In thy soft arms, at last, $\mathrm{O}$, let me fall;

Bright stars are out, long gone the burning sun;

My little act is over and the tiresome play is done

It is unclear as to what eventually happened to the murals. What is known, however, is that they were moved to the University of Michigan in Ann Arbor in 1931 by John Barnwell when the Lea Cabin was torn down. In 1959, they were deteriorating, and Barnwell arranged for them to be moved back to the Trudeau Sanatorium where they were handed over to the Trudeau Foundation. In 1967, the murals were shipped in crates to the John F Kennedy Special Warfare Center in Fort Bragg. Since then, several people, including Wilder Penfield, a world-renowned Montreal neurosurgeon, have tried to recover them but all their efforts were futile. According to some, it is possible that the murals may have been destroyed by the Americans after they had studied them, trying to understand the workings of a 'communist mind'!

During his year at the sanatorium, Bethune's social attitudes were deeply etched by his experience with tuberculosis and he came to recognize that the disease was, in large measure, the result of poor socioeconomic conditions (1). He felt that this should be a concern to all physicians.

\section{CIVILIAN THORACIC SURGICAL WORK IN MONTREAL (1928-1935)}

In 1928, Bethune wrote to Edward William Archibald, then Professor and Chairman of the Department of Surgery at McGill University in Montreal, asking for further training in thoracic surgery. Archibald suggested that he first spend a preliminary three-month period at Ray Brooks State Hospital for tuberculosis in New York. During that time, Bethune completed a study on pseudotuberculosis in rats, and Director David T Smith later said: "Bethune learned more about bacteriology in three months than most graduate students learn in three years."

At completion of this preliminary period, Bethune joined Archibald at the Royal Victoria Hospital (Royal Vic), first as a fellow and then in 1930, as a clinical assistant. Interestingly, Bethune never obtained a license to practice surgery in the province of Quebec but he nevertheless was allowed to operate at the Royal Vic. Under Archibald's guidance, he was also encouraged to perform research, which he did, sometimes with unconventional methods. To resolve a debate on whether blood is spontaneously absorbed from the lung, for instance, he had a catheter placed in his own trachea, through which blood was instilled overnight (1). 


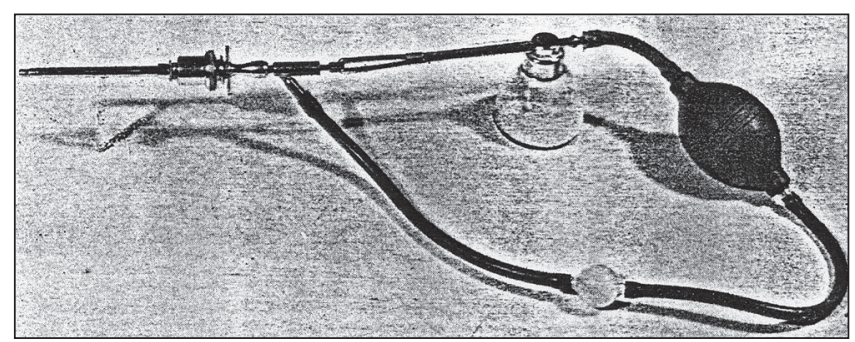

Figure 10) Bethune's return-air pleural powder blower (reproduced with permission from reference 11)

During his years in Montreal, Bethune wrote 16 scientific papers, most of them of significance, became a councilor of the American Association for Thoracic Surgery, and designed most of the thoracic surgical instruments used at the time (10). These include the rib shears, still used today and which was a copy of leather-cutting shears made in Montreal by the United Shoe Machinery Company; the periosteal scraper, forerunner of the periosteal elevator; and a table-mounted scapula retractor, also called the 'iron intern', used to elevate the scapula during the upper stage of a thoracoplasty (Figure 9). These instruments were manufactured in the United States (Philadelphia) by the Pilling Company and were prominently displayed in their sale catalogue. In his 1936 publication (10), Bethune wrote the following about those instruments for which he never received any money:

The instruments and apparatus about to be described are the survivors of as many more again, ill-conceived or immature ideas. They were designed to improve craftsmanship, and have been modelled, remodeled and tested over a sufficiently long period of time (most of them from two to five years) to warrant description.

Bethune was the first ever to insufflate talc in the pleural space when, in 1934, he described its use to anchor pulmonary lobes so that they remained in position during the resection of other lobes (11). At the time, this feature was considered to be the chief obstacle to successful lobectomy. To do so, he used a Jacobeus thoracoscope and a return-air pleural powder blower (Figure 10), similar to what is still currently used for talc poudrage.

He became a recognized figure at surgical meetings where his attire and antiestablishment behaviour often stimulated as much discussion as his presentations. His ability for self-criticism, when others might well have chosen to conceal their errors, is perhaps best exemplified in a paper entitled "Some Errors in Technique and Mistakes in Judgment made in the course of 1,000 Thoracic Surgical Operations" that he presented at the annual meeting of the American Association for Thoracic Surgery held in Rochester, Minnesota on May 6, 1936 (Paper no 25). The abstract read as follow: "Twenty-five 'howlers' have been collected and will be presented".

Contrary to usual practice, the paper was turned down for publication in the Journal of Thoracic Surgery (Evarts Graham, editor) because it was considered too provocative.

Bethune was an enthusiastic, well-informed and gifted teacher who used small-group approaches. He listened to what students had found on clinical examination and was thoughtful when he expressed himself, often unequivocally (12). He enjoyed ridiculing standard practices. His energetic pursuit of new approaches was refreshing to young trainees, who had endured what they considered to be excessive formal teaching.

As a surgeon, Bethune had developed a reputation for speed in the name of minimizing shock and duration of anesthesia. Although some colleagues were impressed with his concern for patient's welfare, others were taken aback by what appeared to be reckless operative technique. One day, a clinical clerk said that "he had become aware that Dr Bethune's patients had a rocky time recovering from surgery and that, in spite of their best care, they were losing them at an unusual rate" (6).

\begin{tabular}{|lrlr|}
\hline $\begin{array}{l}\text { TABLEAU 4 } \\
\text { Interventions }\end{array}$ & chirugicales en & $\mathbf{1 9 3 3}$ & \\
\hline Bronchoscopies & 15 & Pleuroscopies & 6 \\
Costotomies & 11 & Plombage & 1 \\
Jacobeus & 11 & Pneumolyse & 1 \\
Laryngoscopies & 1 & Ponctions & 10 \\
Lavage des plèvres & 11 & Poudrage pleuraux & 3 \\
Lipiodols & 53 & Thoracoplasties & 60 \\
Lobectomies & 3 & Thoracoscopies & 10 \\
Phrénemphraxis & 4 & Transfusions & 7 \\
Phrénicectomies & 43 & & Totaux \\
\hline
\end{tabular}

Figure 11) Recording of cases performed by Norman Bethune in 1933 at l'Hôpital Sacré-Coeur in Montreal, Quebec

Bethune was always willing to perform surgery on patients with severe tuberculous lesions that had often been rejected by others, including Archibald. His philosophy was that patients had nothing to lose because surgery could cure some of them.

By 1932, the general antipathy toward Bethune at the Royal Vic and Archibald's increasing irritation with Bethune's frequent and pointed criticisms suggested the need for a change. This did not come as a surprise because of their contrasting characters, personal morals and surgical skills. In his book on the history of thoracic surgery in Canada (13), Dr Norman C Delarue wrote the following about Archibald and Bethune:

No two surgeons could possibly have been so diametrically opposed in their outlook on life in general or their profession in particular. Only in their convictions about the place of compression in the treatment of tuberculosis did they share any common ground.

In a letter dated December 27, 1940 sent to Dr Gabriel Nadeau, himself an expert on the life of Norman Bethune (14), Archibald wrote the following about Bethune (15):

He was definitely abnormal, but not mental, and not a genius nor a leader. He was clever in mechanical things, and could have easily been one of those inventors whose inventions succeed enormously. He was an egocentric. His vision was keen but narrow. He trod on many toes, quite often without knowing about it or without caring if he did know it. He had a superiority complex and was entirely amoral. And yet, it is not fair to say all that, because I do give him credit for sincerity in his social views.

When Dr GE Mignon, chief of surgery at l'Hôpital du Sacré-Coeur, located just north of Montreal, asked Archibald to help him find a qualified thoracic surgeon to head their new Division of Bronchoscopy and Thoracic Surgery, Archibald recommended that they appoint Bethune. It was to take approximately one year to convince the Archbishop that a 'Protestant anglophone' should be appointed to a senior post in their 'Roman Catholic francophone hospital' (12). Although initially looked at with suspicion by the nuns (Soeurs de la Providence) who had heard that he led a 'Vie de Bohème', his surgical colleagues, Drs Georges Deshaies and Gérard Rolland, the anesthetists and the respirologists (Dr J Avila Vidal), came to admire him and, for once, Bethune was happy.

He performed between 250 and 300 cases per year (Figure 11), created a blood bank, used blood transfusions with blood usually drawn from patient's relatives, did one of the first-ever successful pneumonectomies' in a child, and trained his French-speaking successors. He had a profound influence on Dr Cousineau, one of the most prominent Canadian anesthetists of that era. That influence motivated Dr Cousineau to perform pioneering work in thoracic anesthesia (16), and eventually reduce operative mortality in patients undergoing thoracoplasty by using thoracic epidural blocks 


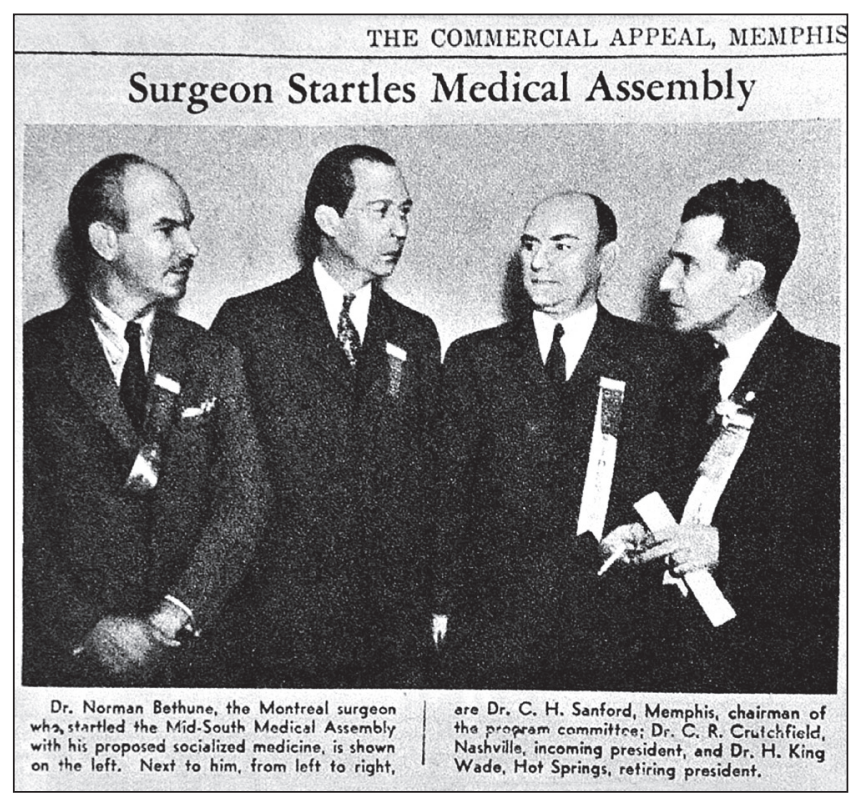

Figure 12) In 1936, Bethune was invited to Memphis to give a lecture on "Advances in Anesthesia for Thoracic Surgery" to a very conservative group, the Mid South Medical Assembly. After his talk on spinal anesthesia, Bethune presented, unannounced, his thoughts on socialized medicine. This newspaper clip from the "Commercial Appeal, Memphis" shows a radiant Bethune (on the left) alongside officers of the assembly averting their eyes from Bethune

instead of ether anesthesia (17). Dr Cousineau said the following about Bethune (18):

He always stayed with his post-operative patients until he felt that they were safely recovering. If the patient died, he would himself do the post-mortem examination to document what had gone wrong. He was a great Professor. He lead a clinical conference every Friday.

\section{SOCIAL CONSCIOUSNESS AND ADVOCACY OF SOCIALIZED MEDICINE IN CANADA (1935-1936)}

Although several specialists in Public Hygiene and Public Health were committed to improve the sanitary conditions that prevailed in Canada during the first one-third of the 20th century, the medical profession, as a whole, stayed away from that movement. At the time, there were major propaganda campaigns to better public health, most notably through education and improvement of local hygiene, but few doctors were involved in those campaigns and few mentioned publicly socioeconomic disparities as a cause of the high rate of infectious diseases and perinatal mortality, even if they knew very well that there was a close link between the two. To explain the high perinatal mortality, for instance, doctors preferred to minimize the impact of poverty and rather emphasize mother's ignorance. Ultimately, this attitude allowed doctors to escape the all-important issue of free access to health care.

Doctors practicing in major hospitals were treating injured workers on a daily basis and witnessing, first-hand, the obvious negligence of the employers, yet very few were willing to denounce the dangerous workplace conditions or get involved in reform movements. Even if some public hygiene specialists had been given the mandate to inspect workplaces since the Bill named "Loi des Manufactures" had been adopted in 1885 , these people were few and they virtually had no power to turn things around. The "Commission d'enquête sur les accidents de travail" created in $1907 \mathrm{had}$, indeed, documented that the situation was deteriorating. Because of their traditional conservative attitude, the doctors preferred low-profile individual actions rather than being involved in more radical movements. They also did not wish to work with the government in trying to eradicate what was believed to be one of the negative impacts of capitalism (19).
In the early 1930s, Montreal and the whole of Canada were in the depths of a severe economic depression and very few individuals wanted to have any kind of involvement in social reforms. Among those few, however, was Norman Bethune, who had become horrified with the disastrous sanitary conditions that prevailed in Montreal and mostly affected the poor. In the spring of 1935 , he began to write a booklet exposing the bad sanitary conditions and status of health care in the province of Quebec and wrote the following (20):

Bring it out into the light of the day "he told his friends" and then stir up enough feeling to get something done. Put it in terms that the people can understand, and may be some of the babies now dying in this "benighted" land will have a chance to be saved. The facts will be more important than all the pious platitudes in the world.

Bethune was extremely critical of the medical profession and of how doctors were practicing medicine. According to Allan and Gordon, he said the following about doctors (20):

We set ourselves in practice, all smug and satisfied, like tailor shops. We patch an arm, a leg, the way a tailor patches an old coat. We're not practicing medicine, really, we're carrying on a cash-and-carry trade. I'll tell you what's needed: A new medical concept of universal health protection, a new concept of the function of a doctor

Bethune always felt that if poverty could be eliminated, tuberculosis would disappear. On joining l'hôpital du Sacré-Coeur, he freely provided his services to the poor and established a free-of-charge clinic, which was held on Saturday mornings in the Montreal suburb of Verdun. He was way ahead of his time in using radio broadcasts for public education on tuberculosis. In a paper published in 1932 in the Canadian Medical Association Journal (21), Bethune quoted a remark made by Edward Livingston Trudeau, the sanatorium founder:

There is a rich man's tuberculosis and a poor man's tuberculosis. The rich man recovers and the poor man dies.

Bethune added:

We, as a people, can get rid of tuberculosis, when once we make up our minds it is worthwhile to spend enough money to do so. Better education of doctors, public education to the point of phthisiophobia, enforced periodic physical and X-ray examinations, early diagnosis, early bed-rest, early compression, isolation and protection of the young are our remedies.

Frequently, Bethune and Dr J Avila Vidal, one of his medical colleague and good friend, would bring food, clothing and medicine for the patients.

Along with a seven-member Canadian delegation that included Hans Selye and Frederick Banting, Bethune attended the First International Physiological Conference held in Leningrad during the summer of 1935, a conference chaired by Pavlov of the conditioned reflexes. He quickly abandoned the official agenda and wandered around to see Russia and what the country was doing for tuberculosis. He became deeply impressed with the socialized Soviet medical system and its success in controlling tuberculosis and, in October 1935, joined the Canadian Communist Party as a "close member", which meant that his membership was kept secret.

In December 1935, he began a crusade to reform the Canadian health care system by founding the Montreal Group for the Security of the People's Health, later renamed the Montreal Social Medicine Group. The Group, which included professionals of different disciplines, met on a regular basis to look at options to improve the quality of health care which they believed was unjust, inefficient and wasteful. Ultimately, the Group's main objectives were to stimulate some discussion as how to better use medical care and medical profession to improve people's welfare and elaborate an action plan which would allow all sick people to benefit from the best of medical care. 


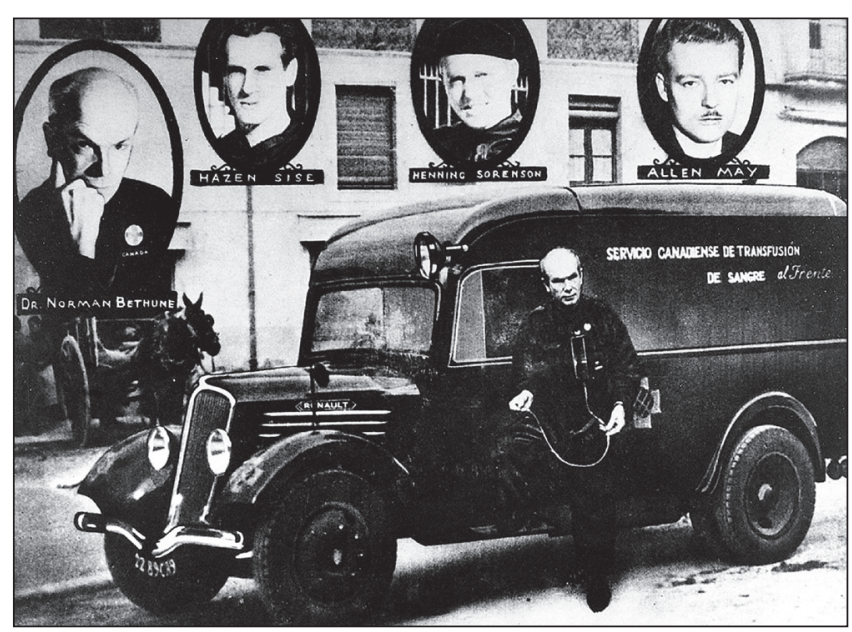

Figure 13) Photograph of the blood transfusion vehicle, called The Canadian Blood Transfusion Service at the Front, and members of Bethune's team. The insets picture Bethune, Hazen Sise, Henning Sorensen and Allen May

To this end, the Group proposed a scheme for socialized health care that included security for people (ie, municipal and provincial government-subsidized compulsory health insurance) and economic security for the medical profession (ie, salary for doctors). Bethune enjoyed speaking publicly on the subject and, according to Dr Lloyd D Maclean, former Chief of Surgery at the Royal Vic, he was a popular, engaging, lively and well-informed performer (12) (Figure 12).

The Group eventually forwarded a manifesto in support of socialized medicine to candidates for the upcoming 1936 provincial election, the Premier of Quebec, the mayor of Montreal, and other health professionals but the manifesto was greeted with complete public indifference. There were even hostile comments from both politicians and doctors. Bethune's ideas were believed to be too radical and, at the time, fear of communism and socialism was very strong in Canada. Interestingly, most of Bethune's suggestions became effective in Canada in 1970, more than 35 years later.

Sometime in the mid-1930s, Bethune was driving colleagues to his apartment when, unexpectedly, they found themselves in the middle of a protesting crowd of several thousand men and women carrying a white banner on which was written "Milk for our children! Bread for our wives, and Jobs" (20). When a double line of horsemen broke their mounts into a trot and charged into the crowd, Bethune did his best to provide first-aid medical care to the wounded. The next day, the leaders of the Montreal Unemployed Association (Association des Chomeurs de Montreal) were meeting in their office when, suddenly, the door flew open and an expensively tailored individual walked in. He extended a card to them and said (19):

I am Dr Norman Bethune. Any man, woman or child you send me will receive medical treatment free of charge. By next week, I hope to have another ten doctors doing the same.

\section{PARTICIPANT IN THE SPANISH CIVIL WAR. FIRST MOBILE BLOOD TRANSFUSION SERVICE (1936-1937)}

In July 1936, the outbreak of the Spanish Civil War gave Bethune the opportunity to fight for the communist cause and against fascism. This was a conflict between the Republicans Loyalists duly elected by the Spanish population and the fascists led by Franco, and supported by Hitler, Mussolini and, many say, the Spanish Catholic Church. Bethune viewed the conflict as a matter of 'Republican good versus Fascist evil'.

With some prominent Canadian antifascists, he helped form the Committee to Aid Spanish Democracy and, in late October 1936, sailed from Quebec City to Spain. Once in Madrid, he quickly realized that the Republican forces needed a blood transfusion service and a

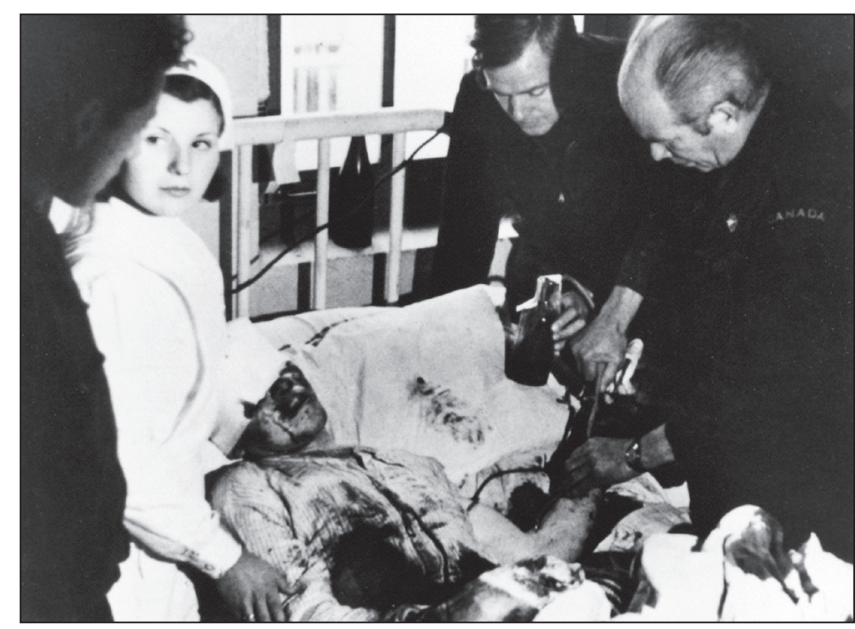

Figure 14) Norman Bethune (standing, right) transfusing blood to a wounded soldier during the Spanish Civil War

blood bank (8), a concept that he had likely learned from Archibald, who had himself used blood transfusions during World War I (22).

When the Spanish authorities received his ideas with great enthusiasm, he left for France and England to buy equipment and learn the latest techniques in blood typing, storage and transfusions. On his return to Spain, he designed a mobile transfusion vehicle that incorporated a refrigerator, a sterilizing unit and an incubator (23). The unit, called Servicio Canadiense de Transfusion de Sangre Al Fiente (Figure 13) also contained equipment and containers for drawing and giving blood transfusions on the battlefield. Alexander Walt wrote the following about Bethune's heroic actions in Spain (1):

Bethune was in his element, working in an arena of high drama, courting danger, helping the wounded, improvising, and achieving immediate and gratifying results. Above all, like a guerrilla, he was mobile and his own master.

The service grew rapidly and, within months, it was supplying blood to every military sector along a $1000 \mathrm{~km}$ front. Although Bethune referred to it as a "glorified milk delivery service", his mobile blood bank service has been called one of the "greatest innovation in military medicine" (24). It was, indeed, the first front-line mobile blood transfusion unit in military medical history (Figure 14). Bethune himself wrote (6):

We have succeeded in unifying all remaining transfusion units under us. We are serving 100 hospitals and casualty clearing stations in the front lines... This is the first unified blood transfusion service in army and medical history. Plans are well under way to supply the entire Spanish anti-fascist army with preserved blood .

The 'Institute' is now operating on a 1,000 kilometer front.

To do so, Bethune established a blood transfusion centre in Central Madrid and, aided by publicity on the radio and in the press, it had 1000 donors in its books by the end of 1936. A pool of donors was thus always on hand and they could be called, if necessary, every three weeks for donation. According to one author (23), the unit transfused approximately $5000400 \mathrm{~mL}$ blood flasks that, based on Loyalist army statistics, accounted for nearly $80 \%$ of all transfusions done during the Spanish civil war.

Particularly notable was Bethune's concept of taking blood to the wounded on the battlefield or in casualty stations, thus saving many lives that would otherwise have been lost during prolonged extractions. The paramedics who were created during World War II became an extension of his ideas.

In February 1937, Bethune set off with his unit to the besieged city of Malaga on the South coast of Spain. On the road, he encountered 


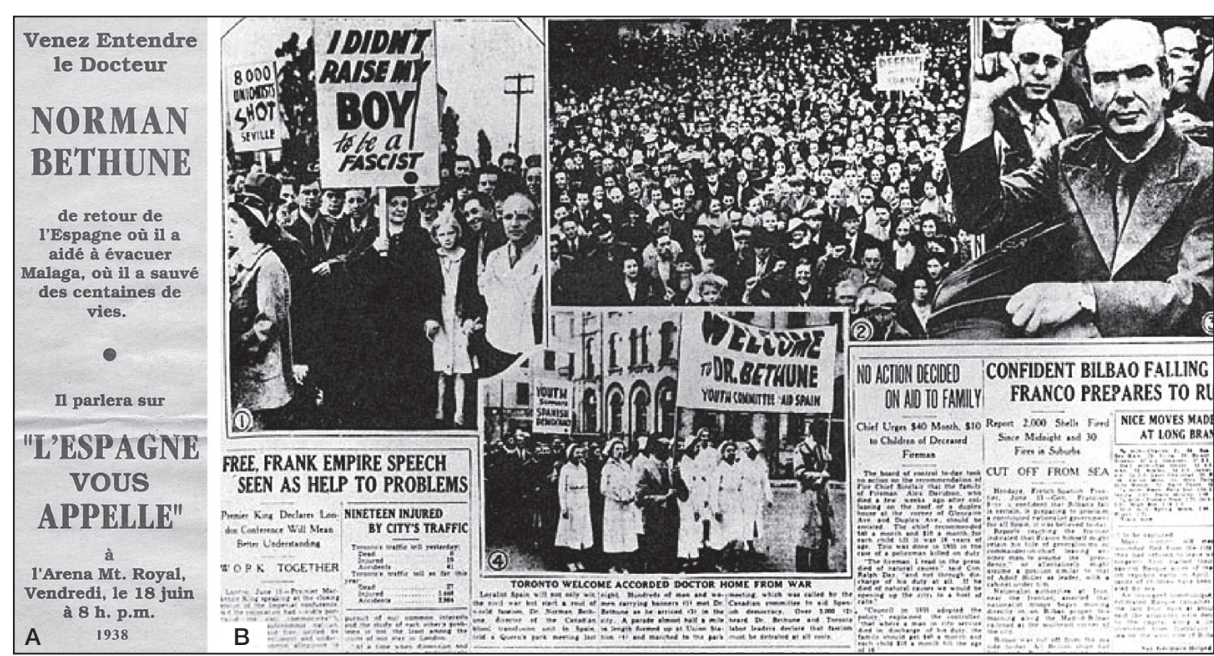

Figure 15) A French advertisement asking people to come and hear "Bethune who had just come back from Spain where he had helped save hundreds of lives"; B Large crowds gathered to hear Bethune speak against fascism

more than 40,000 refugees fleeing to Almeria, $160 \mathrm{~km}$ away, carrying children and possessions. Those who could go no farther lay down beside the road to die. For three days, Bethune and his unit ferried the most desperate to the safety of Almeria. Then, Almeria too was bombed.

Lack of discipline, heavy drinking, fatigue, communication breakdown and bureaucracy (Bethune's Spanish hosts had decided to take control of his transfusion units) were his downfall and, eventually, his colleagues and friends persuaded him to return to Montreal to raise funds for the Committee to Aid Spanish Democracy. He arrived back in Montreal in June 1937 to a triumphant welcome. More than 1000 people met him at Windsor Station and, that night, 8000 more heard him speak on the bravery of the Spanish people, the failure of the international community to assist and the high likelihood of an upcoming antifascist world war (Figure 15). The following is what one of Bethune's former colleagues remembers about the speech he gave upon his return from Spain (18):

We went to his anti-fascist speech delivered at the 'Arena Mont-Royal' which, for the occasion, was packed. We were hiding in the upper section of the arena because we wanted to avoid being seen at a meeting organized by the 'Co-Operative Commonwealth Federation', precursor of the New Democratic Party, and the Canadian Communist Party.

Bethune soon embarked on a tour of Canada and the United States, and his first speaking engagement was on the lawn of the Ontario legislature buildings in Toronto. He was a forceful speaker but a mixed blessing for the Communist party of Canada, which exploited his reputation and fund-raising abilities but found that his unorthodox approach and his intolerance of party discipline were of some concern!

\section{BETHUNE IN CHINA. THE MAKING OF A HERO} (1938-1939)

In October 1937, Bethune, now 48 years of age, recognized that the Sino-Japanese conflict in the most populous country in the world was to be a momentous event and he was able to convince the Canadian Communist Party and the China Aid Council based in New York to send him to China to organize medical care for Mao Tsé-Tung's Eight Route Army, one of the main military forces of the Communist party of China. In early January 1938, he traveled from Vancouver to Hong Kong (Figure 16) with Jane Ewen, a Canadian nurse from Winnipeg. It took them a further three months to travel by train, by horse and on foot under daily Japanese attacks to reach Yenan in northern China (Figure 17), where Mao's headquarters were located.

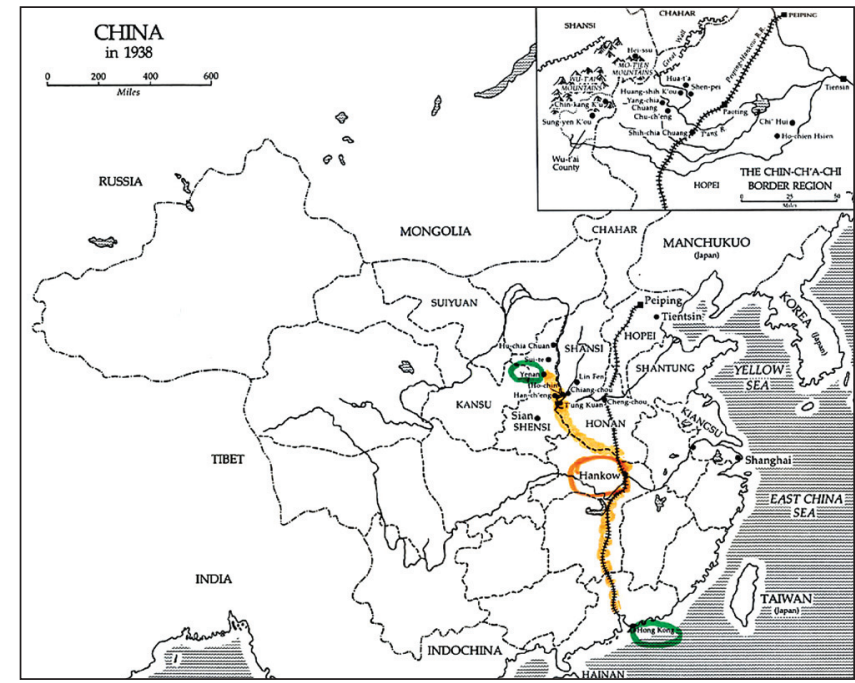

Figure 17) Map showing the road taken by Bethune and Jane Ewen to reach Mao's headquarters in Yenan in northern China

On arrival in Yenan, he met Mao (Figure 18), who had heard of Bethune's heroics in Spain and wanted him to duplicate these efforts in China. Bethune's plan was to establish mobile surgical units and travelling blood banks, and he assured Mao that he could reduce casualty mortality rates by $75 \%$. Soon after, he was made Commander of all Chinese medical forces. The fact that Bethune was a card-carrying communist with credentials from the Communist Party of Canada was instrumental for him to get accepted by Mao and the Eight Route Army.

He resumed performing surgery after two years without having done any operating (Figure 19), and he not only treated war wounds but also took time to deal with civilian illnesses as well. He renovated existing primitive hospital facilities and opened a 'model hospital' in a Buddhist temple on September 15, 1938. Unfortunately, the hospital was destroyed by the Japanese forces three weeks later. The hospital was eventually relocated in Shijiazhuang and renamed the Bethune International Peace Hospital. The hospital still exists today and has become a 2000-bed ultramodern facility.

Recognizing that his Chinese colleagues were completely untrained but dedicated, intelligent, anxious to save and aspiring to be of aid to suffering mankind, he gave them daily courses on basic anatomy, physiology and how to treat minor wounds. He understood that more doctors and nurses were needed, and he took young peasants, whom 


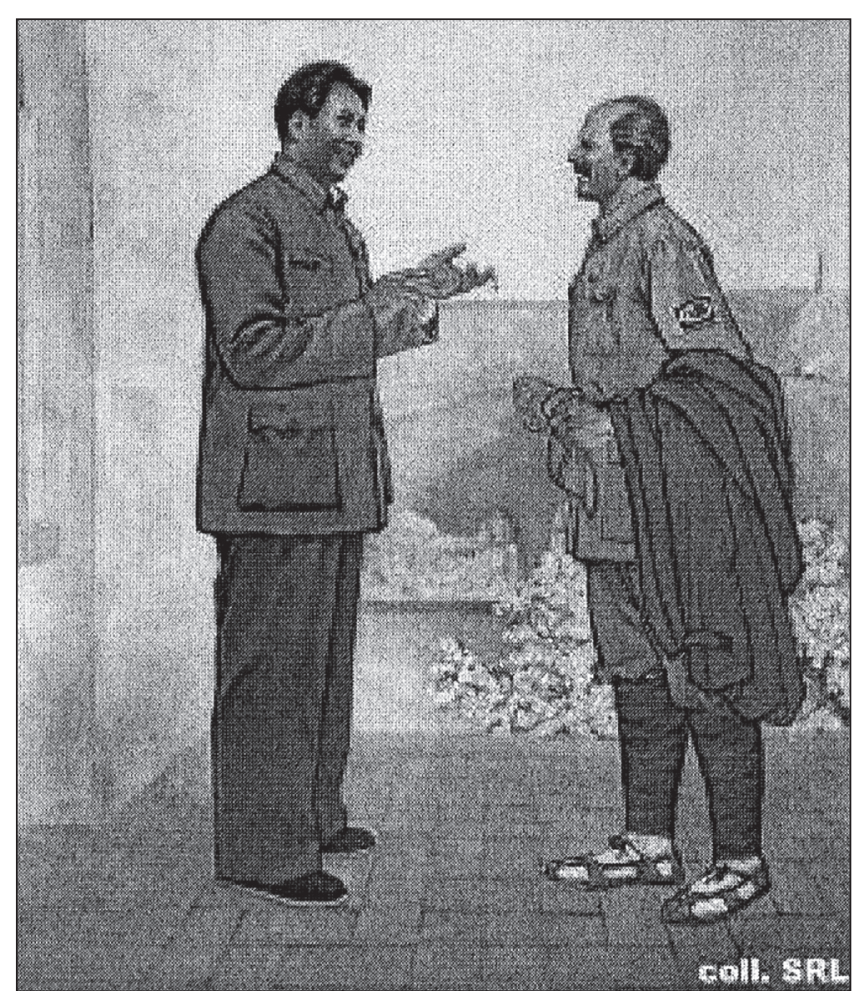

Figure 18) Painting of the historical meeting between Mao and Bethune upon Bethune's arrival in Yenan. No photographs were taken during that one and only encounter between Mao and Bethune

he called "barefoot doctors, docteurs aux pieds nus" and graduated them in one year for doctors and six months for nurses. In a letter to Dr Louis Davidson, a well-known New York thoracic surgeon, which was reprinted in the Baltimore Evening Sun on January 13, 1940, Bethune wrote the following (25):

The work I am trying to do is to take peasants (boys) and young workers and make doctors out of them. They can read and write and most have a knowledge of arithmetic. None of my doctors has ever been to college or universities, and none has ever been in a modern hospital (most of them have never been in any hospital), much less a medical school. With this material, I must make doctors and nurses out of them- six months for nurses and one year for doctors-. We have 2,300 wounded in hospitals all the time. These hospitals are merely the dirty, one-story mudand-stone houses of out-of-the-way villages set in deep valleys, over hung by mountains, some of which are 10,000 feet high.

After the war, barefoot doctors became very important in the Chinese health care system because they could provide medical services in rural communities. At one point, there were more than one million barefoot doctors in China, but they no longer exist, having been gradually replaced by 'administrators'. Bethune laid the groundwork for a medical school, now located in Changchun, Jilin province, and wrote an English medical textbook that was later translated in Chinese (Figure 20). In modern China, the Jilin University medical school founded by Bethune is one of the few to be recognized as an Advanced Institute by the Central Government. This is where, one of the authors of this manuscript (JD) spent a sabbatical year in 2008-2009.

He designed operating equipment, which included a collapsible operating table, antiseptics and sterile gauzes that could be packed in wood boxes (Figure 21) and brought to the battlefields on the backs of three mules. Most, if not all, of the surgical instruments that he used were made by local carpenters and blacksmiths. The operating unit included Bethune, two Chinese doctors, one interpreter that Bethune

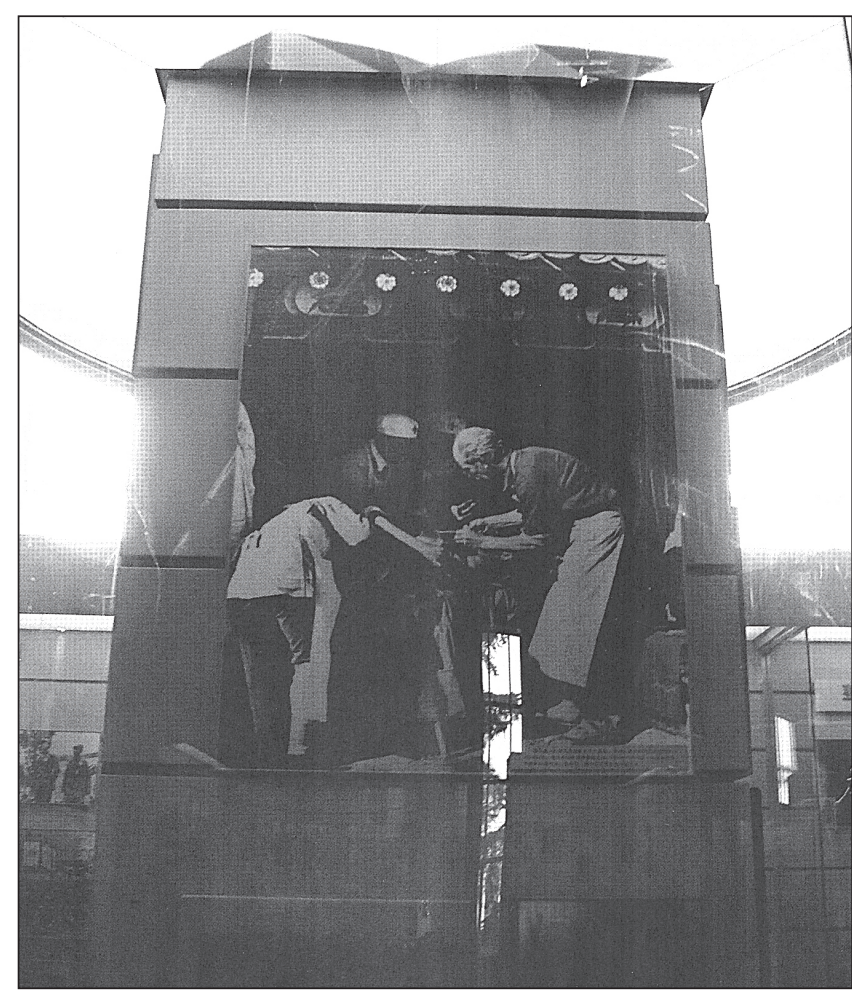

Figure 19) Bethune operating bare-handed in a small temple in Sunjia village, Hebei province, in 1939

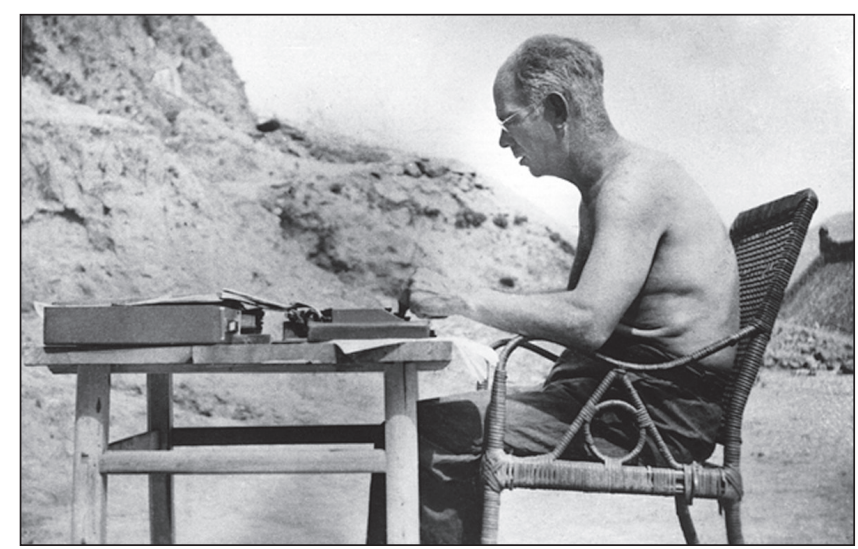

Figure 20) Photograph of Bethune writing a medical text in 1939

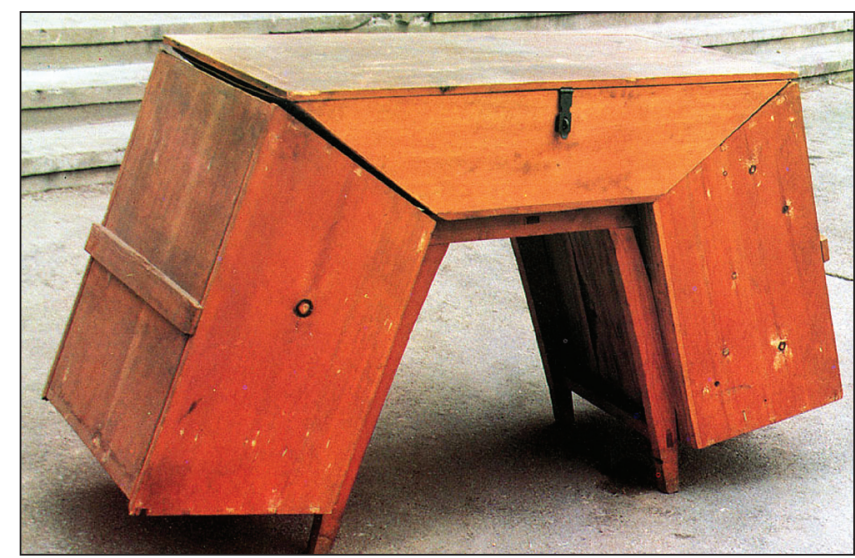

Figure 21) Original wood box used by Bethune to carry operating equipment to the battlefields of China. These wood boxes were carried on the backs of three mules 
had trained as an anesthetist, a cook and two orderlies. Bethune's stamina, his ability to improvise, and the speed and relative roughness with which he operated (so frequently criticized in his Montreal days) now became indispensable assets (1). He would often be warned ahead of time that a major battle was to take place (Figure 22) and he would move his unit and equipment near the battlefield. His slogan was: "Doctors go to the wounded; do not wait for the wounded to come to you".

He took soldiers as brothers and treated villagers as his relatives. When soldiers heard that Bethune would be at the front to take care of the wounded, they chanted: "Attack, attack, Bethune is with us".

On October 28, 1939, he cut his finger with an osteotome while doing an open reduction of a fractured tibia, and some days later, he operated bare-handed on a soldier whose scalp injury was infected. Interestingly, Bethune did most of his operating in China bare-handed, not only because surgical gloves were unavailable but also because he preferred it that way. On November 11, he wrote the following:

I came back from the front yesterday. There was no good of my being there. I couldn't get out of bed or operate... I think that I have septicemia or typhus fever.

Soon after, an abscess of his finger developed, followed by upper limb gangrene, and sepsis. Bethune, who was conscious to the end, and who had refused to have his arm amputated, died on November 12, 1939, only 18 months after his historical meeting with Mao. Of note, Bethune had given some time before his personal supply of sulfamides to wounded soldiers.

A long procession of comrades and soldiers carried his body for four days along icy mountain paths to a place of relative safety in Shansi where he was buried in a United States flag because no Union Jack flag could be found. In 1952, his remains were taken to the Revolutionary Martyr's Cemetery (Figure 23) in the suburbs of Shijiazhuang, located approximately $300 \mathrm{~km}$ from Beijing. Across the street from the cemetery is the Bethune International Peace Hospital, where a memorial hall inside the hospital attracts thousands of visitors every year.

\section{CONCLUSION}

Mao Tse-Tung's eulogy following Bethune's death written on December $21^{\text {st }}, 1939$, is now mandatory reading and memorizing by all Chinese schoolchildren. Mao wrote the following:

Comrade Norman Bethune... died a martyr at his post... his utter devotion to others without any thought of self... the art of healing was his profession... his example is an excellent lesson.

Bethune was the first and last foreigner to receive such high praise from Chairman Mao. His truly Herculean efforts in organizing the then primitive health care in China, in training personnel, and in establishing hospitals under the most frightful circumstances set a mark of greatness on him that no one can deny. His courage, determination and will to fully employ his talents of ingenuity, aggressiveness and selfless response to social concerns when the time came is truly remarkable.

In Canada, his reputation was long tainted by his unconventional personality, his membership in the Communist Party, and his advocacy of socialized medicine. Belated recognition was granted in 1972 when the Federal government declared him "a Canadian of National Historical Significance”. The Presbyterian manse where he was born (Figure 2) was restored to period and a portion of it converted into a museum. It was opened in 1976 as the Bethune Memorial Home.

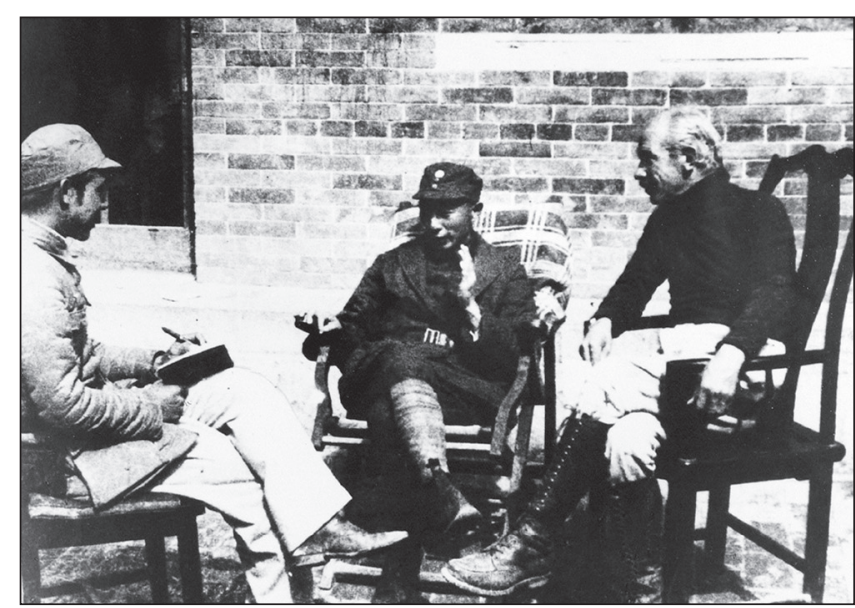

Figure 22) Bethune was told ahead of time where a battle was to take place and he would move with his staff and equipment near the battlefield. On this photograph, Bethune is speaking with General Rong-Zhen Nie (centre) and a Chinese journalist

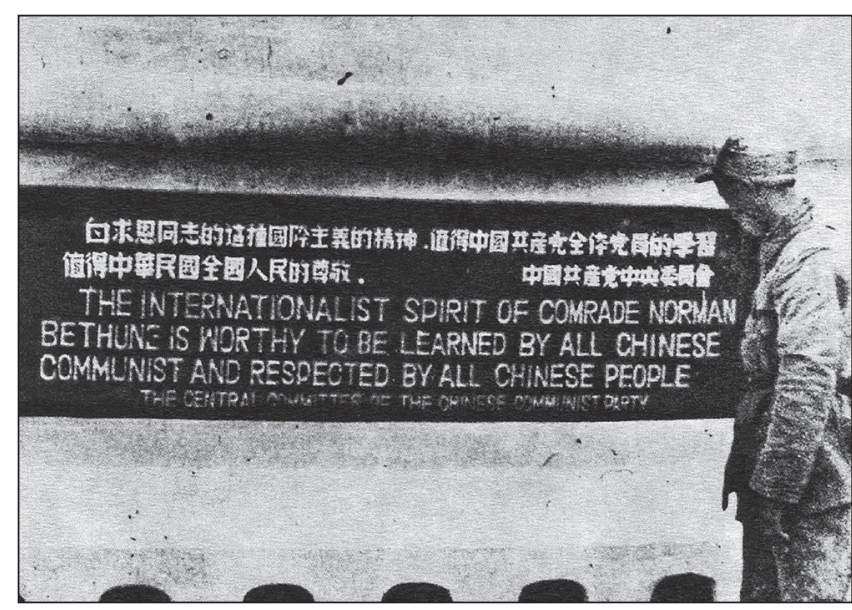

Figure 23) Bethune's remains are buried in the Revolutionary Martyr's Cemetery in the suburbs of Shijiazhuang in the People's Republic of China

In November, 1979, a Canadian delegation was invited by the People's Republic of China for the 40th anniversary of the death of Norman Bethune. The delegation was greeted with great friendship as Canadians bearing relationships to Bethune (26).

In commemoration of the centennial of Norman Bethune's birth, Canada and China collaborated in the production of a pair of postage stamps, issued on March 2, 1990. A number of books and films have also been published about his remarkable life.

In 1962, the Chinese Opera Company made their first trip out of China in many decades and insisted on giving a performance at the Royal Victoria Hospital to honor the memory of Bethune (2), and the following year, a Norman Bethune exchange lectureship was established between McGill University and Peking Medical College. The University of Toronto also recognized Bethune's achievements by placing a plaque in his honor in the foyer of its medical school.

In the final analysis, Bethune's posthumous influence may have played an important role in the reopening of relations between China and the West. 


\section{REFERENCES}

1. Walt AJ. The world's best-known surgeon. Surgery 1983;94:582-90.

2. MacLean LD. Discussion of Walt AJ: The world's best-known surgeon. Surgery 1983;94:589

3. Munro CA, Macintyre IMC. The ancestors of Norman Bethune (1890-1939) traced back to the Bethunes of Skye, leading members of the MacBeth/Beaton medical dynasty. J R Coll Physicians 2013;43:262-9.

4. Alexander CA. The military odyssey of Norman Bethune. Mil Med 1999;164:247-50.

5. Shepherd DAE, Levesque A. Norman Bethune - his times and his legacy, Canadian Public Health Association, Ottawa, 1982.

6. Rosen IB. Dr Norman Bethune as a surgeon. Can J Surg 1996;39:72-7.

7. Samuels PB. Two heroes of the class of onety-seven: Part 1. Can J Surg 1990;33:69-74.

8. Samuels PB. Two heroes of the class of onety-seven: Part II. Can J Surg 1990:33:147-51.

9. Forlanini C. A contribuzione della terapia della tisi. Abiazone del polmone? Pneumotrace artificiale? Primo caso di tisi pulmonare monolaterale avanzata curato felicemente col pneumotrace artificiale. Gaz Osp 1882;68:537-9.

10. Bethune N. Some new thoracic surgical instruments. Can Med Assoc J 1936;35:656-62.

11. Bethune N. Pleural poudrage. A new technic for the deliberate production of pleural adhesions as a preliminary to lobectomy. J Thorac Surg 1934;4:251-61.

12. MacLean LD, Entin MA. Norman Bethune and Edward Archibald: Sung and unsung heroes. Ann Thorac Surg 2000;70:1746-52.
13. Delarue NC. Thoracic Surgery in Canada. A story of people, places, and events. The evolution of a surgical specialty. Toronto, BC Decker, 1989.

14. Nadeau G. A TB's progress. The story of Norman Bethune. Bull Hist Med 1940;8:1135-71.

15. Stewart R. Bethune. Toronto, New Press, 1973.

16. Cousineau G, Legault L, Forest L. Twenty years of anesthesia in thoracic surgery. Can Anaesth Soc J 1956;3:192-7.

17. Cousineau G, Legault L. De l'éther à l'anesthésie épidurale en chirurgie thoracique. Union Med Can 1952;81:1313-6.

18. Paré J. L'héritage de Bethune. L'Actualité, 7 Octobre 2009.

19. Goulet D, Gagnon R. Histoire de la médecine au Québec, 1800-2000. Québec, Septentrion, 2014.

20. Allan T, Gordon S. The Scalpel, the Sword. The Story of Doctor Norman Bethune. McClelland and Stewart Limited, Toronto, 1952.

21. Bethune N. A plea for early compression of pulmonary tuberculosis. Can Med Assoc J 1932;27:36-42.

22. Archibald E. A note upon the employment of blood transfusion in war surgery. Lancet 1916;2:429-31.

23. Franco A, Cortes J, Alvarez J, Diz JC. The development of blood transfusion: The contributions of Norman Bethune in the Spanish Civil War (1936-1939). Can J Anaesth 1996;43:1076-8.

24. Notes from Bethune Memorial House. National Historic Site of Canada.

25. Eloesser L. In Memoriam. Norman Bethune, 1890-1939. J Thorac Surg 1940;9:460-2.

26. Barotes EW. Dr Norman Bethune: Inspiration for a modern China. Can Med Assoc J 980;122:1176-84. 


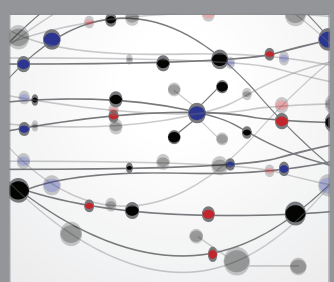

The Scientific World Journal
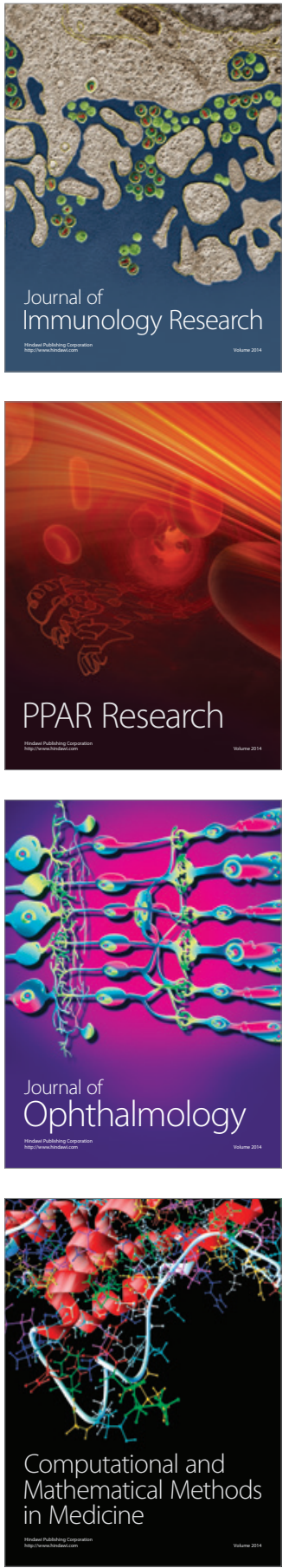

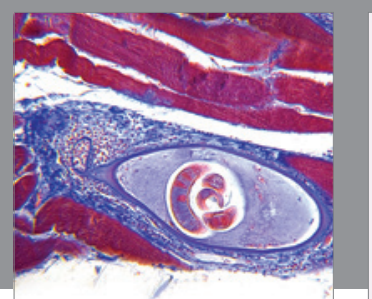

Gastroenterology Research and Practice

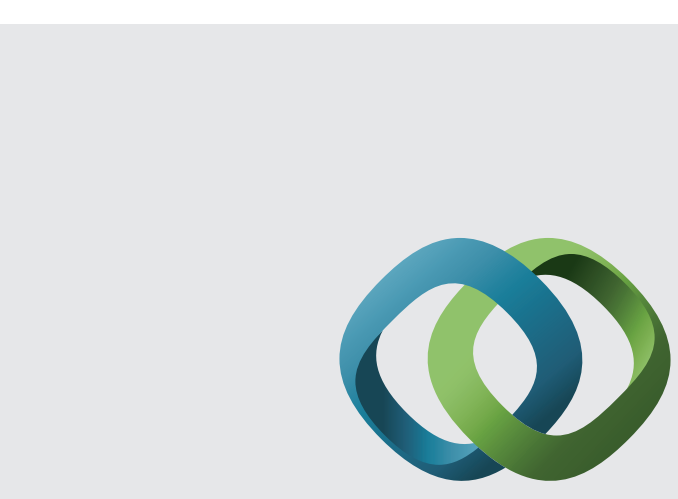

\section{Hindawi}

Submit your manuscripts at

http://www.hindawi.com
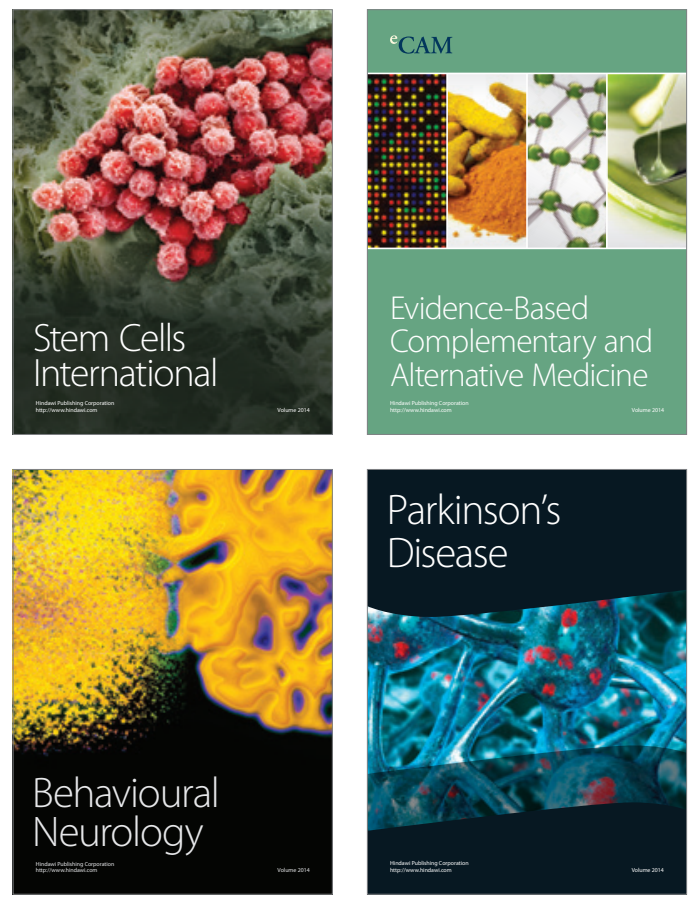
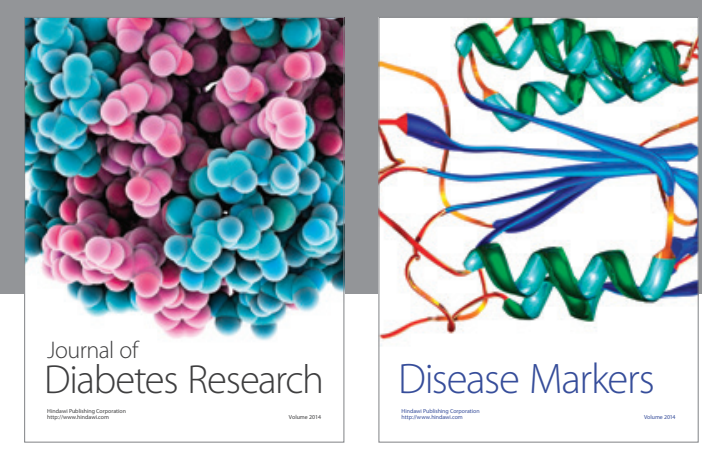

Disease Markers
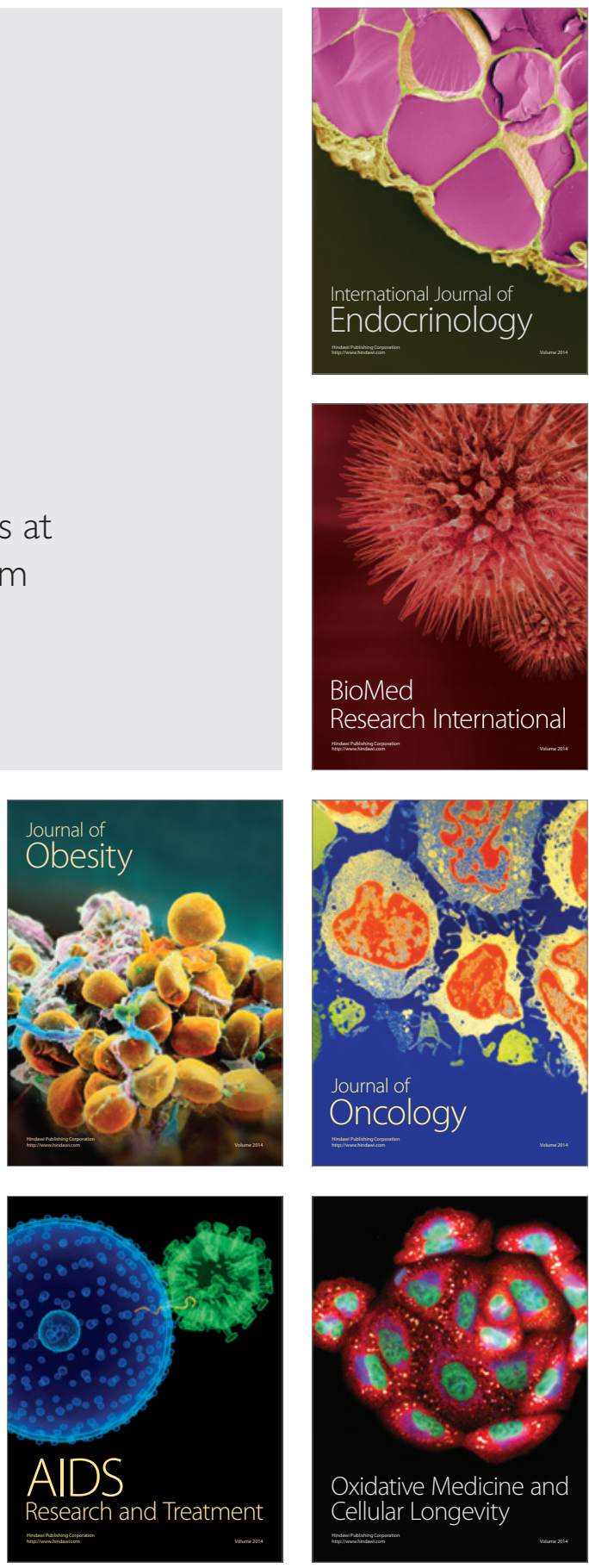